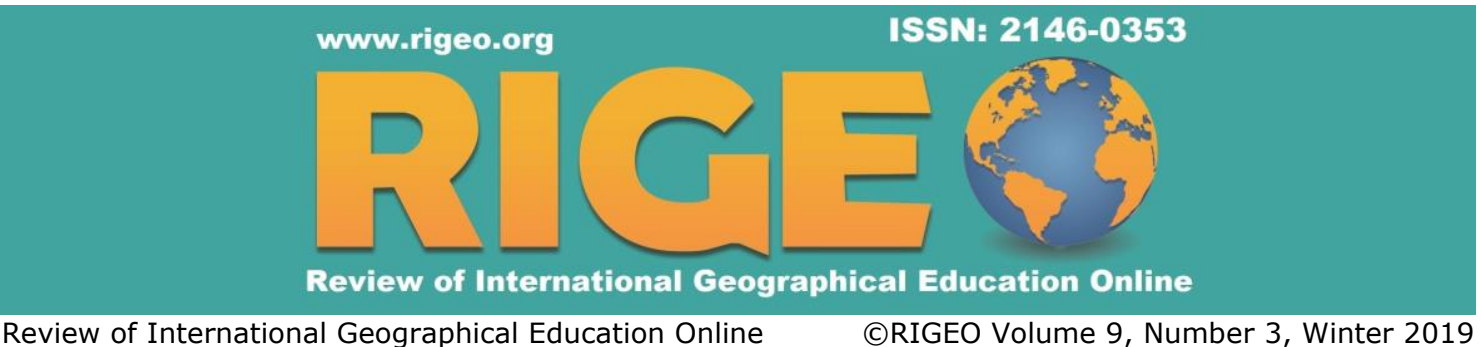

To cite this article: Selanik Ay, T., Öncü, Z. (2019). An analysis of the documentary entitled "Talisman of The City" as a teaching tool in the values education. Review of International Geographical Education Online (RIGEO), 9(3), 639-662. Retrieved from http://www.rigeo.org/vol9no3/Number3Winter/RIGEO-V9-N3-9.pdf

DOI: $10.33403 /$ rigeo.569492

Submitted: May 23, 2019

Revised: September 30, 2019

Accepted: November 15, 2019

\title{
An Analysis of the Documentary Entitled Talisman of the City as a Teaching Tool in the Values Education
}

\author{
Tuğba SELANİK AY ${ }^{1}$ \\ Afyon Kocatepe University, TURKEY \\ Zeynep ÖNCÜ 2 \\ Afyon Kocatepe University, TURKEY
}

\begin{abstract}
The aim of social studies course is to educate individuals as citizens with national and universal values, to provide them with skills which are required in life contributing to see themselves as part of the society they live in. In this process it can be used literary work and media products. One of the media products that can be employed in social studies courses is documentaries. In addition, documentaries can be employed in value education as a resource. The aim of the study is to analyse the use of a documentary entitled "Talisman of the City" (Şehrin T1lsımı) which was broadcasted on TRT TV website in Turkey. Document analysis was used in the research and each episode (total 50 episodes) are analysed as a document. The data obtained were examined using the descriptive analysis. The findings suggest that the documentary analysed contains most of the values. Those values which are frequently mentioned in the documentary are found to be love, respect and helpfulness. In the context of the elements of cultural heritage, many elements were found in the legends.
\end{abstract}

Keywords

Myth, Documentary, Document Analysis, Value Education, Social Studies Courses

When we consider the problems we face in our daily life, it can be said that most of such problems are caused by human behaviors rather than being technical. These problems are covered directly by the value education (Okudan 2010). One of the media products that can be employed for educational purposes is television. Television has

\footnotetext{
${ }^{1}$ Corresponding author: Associated Professor., SELANIK-AY, Faculty of Education, Department of Turkish and Social Sciences Education, Afyon Kocatepe University, Afyonkarahisar, Turkey. ORCID: 0000-0003-1368-052X

${ }^{2}$ Master Degree Student: Faculty of Education, Department of Turkish and Social Sciences Education, Afyon Kocatepe University, Afyonkarahisar, Turkey. ORCID: 0000-0001-6600-8142
} 
both positive and negative effects and is a dialectical mass media (Arslan 2004). The use of media products for educational purposes has been analysed in numerous studies (Selanik Ay, 2010; Yürük, 2015; Ercan, 2014; Selanik Ay, 2017; Karakuş, 2016; Akpınar, 2015). The course of social studies is among the courses which can be easily related with daily life and in which technology and extracurricular learning can be employed. This course aims to provide students with many acquisitions, values and skills. Although the value education has an interdisciplinary nature for primary education the course of social studies is one of the most eligible courses to provide value education.

There are many different definitions of the concept "value". For instance, Turkish Language Society (2018) defines it as follows: value is a kind of material and spiritual element that is closely related to a nation's social, cultural, economical and scientific qualities and refers to the goals to be achieved and the positive attitudes and acts to ve acquired (Turan and Ulusoy, 2014). Halstead and Taylor (1996) argues that values shape our behavior, affect our decisions about any subject, direct our evaluations about various beliefs and actions and are the principles of our personal integrity, beliefs, ideas and living standards (cited in Bozkurt, 2017, p. 33). Values are also regarded as basic beliefs that help us in making a distinction between correct and incorrect. It is also argued that values are principles that make life meaningful and balanced, allow people to live with others in the society, and raise the quality of the individuals' life (Bostrom 1999, cited in Akbaş 2004). At which stage of life the values should be acquired is one of the issues that is frequently discussed. It is well known that values are first acquired from birth in the family context. However, where the values are systematically and in a planned manner acquired are undoubtedly schools. For systematic implementation of values education activities in schools almost all courses contain something about values. One of such courses is social studies. In-class and out-of-school practices which have the aim of providing students with an opportunity to acquire values can be called the value education in general.

\section{Theoretical Background}

\section{The Importance of Values Education}

During the 21th century as a result of many negative events, including increasing violence, culture degeneration, people's negative views of events and each other the value education has become significant. Globalization process and the new understanding of citizenship in parallel with social, economic and technological changes and developments require new qualities in individuals such as active, participatory, responsible, life-oriented and cooperation with others (Narin, 2007, cited in Bozkurt, 2017). One of the major topics of the value education is about the fact that individuals have lost the past values and cannot easily adopt new ones. Because such individuals are are out of date and unable to adapt to their age which may cause many problems in the development of personality and in the formation of an identity (Demiryürek, 2015). The continuity of social integrity and peace is possible by transferring the social values to new generations. Individuals should acquire the values in accordance with the social 
conditions of the day. Major goals of the value education include the following: to bring out the good characteristics of the child, to improve his personality, and to equip individual with positive behaviors accepted by the general public (Turan and Ulusoy, 2014). Leming (2000) argues that as long as schools exist there will be affective education. Because schools teach that knowledge is more valuable than ignorance and social order is much valuable than social disorder (cited in Akbaş, 2008, p.6). The development and improvement of a society depends only on the education system and values education organized in accordance with that society (Modaqiq, 2017). The focus of the value education is on children. It is the responsibility of educators to make children aware of certain values and enable to produce new ones, and identify with them (Şimşek, 2015). The adaptation of the individual to the society is one of the aims of the value education. The value education helps children and young people to be involved, principled and responsible individuals. It aims at bringing out the good characteristics of the child, improving his personality and his morals (Ercan, 2014). The most important task in realizing all these objectives falls into the values education. The value education plays an important role in the formation of intergenerational bond and of social continuity (Bozkurt, 2017).

The Ministry of National Education (2018) states that in today's democratic societies, as much as academic achievement, many values that regulate human relations are becoming more prominent. Family, community, media as well as educational programs have an important impact on educating individuals who recognize, adopt and internalize national, spiritual and universal values and turn them into behaviors. The values that are included in the educational programs of different courses should be given to the students in order to be gained implicitly by making them felt and experientialized. In the value education numerous resources such as society, literary products, media products, and technology can be employed as educational tools. Major literary products that can be used are legends, stories, novels, poems, stories and tales. The media products that can be used for educational purposes include movies, short films, animations, advertisements, public spots, travel programs, news and cartoons.

There are many studies on the resources that can be used and on the educational activities that can be implemented in the value education (Çıkrıçı1, 1999; Örnek, 2006; Sevim, 2013; Bektaş Öztaşkın, 2013; Demirci, 2013; Deveci, Belet \& Türe, 2013; Akkaya, 2014; Ercan, 2014; Güven, 2014; Akpınar, 2015; Çapaoğlu \& Okur, 2015; Aktan \& K1lıç, 2015; Şimşek, 2015; Öncü, 2015; Karakuş, 2016; Konak, 2017; Uçar \& Karakuş, 2017; Selanik Ay \& Korkmaz, 2017; Aladağ \& Karaman, 2018). These studies focus on the usability of different resources such as newspaper, novel, cartoon, fairy tale, story, documentary, cartoon, myths and periodicals in the process of value education.

\section{The Use of Myths as an Educational Tool}

Myths develop children's imagination as well as they reflect some historical events and heroism in an interesting way. Myths contain surreal items and elements. Therefore, myths cannot be given as facts in educational settings. On the other hand, myths offer several materials that can be employed in the activities designed to make children aware 
of the past traditions, customs, attitudes and values (Öztürk, Coşkun \& Keskin, 2014). Literary work such as legends, tales, stories and myths is mostly verbal narrations and provide complex events using the event motives in an organized manner. They have very important functions such as culturing and transferring different messages. In the ages when formal education was not yet available, the function of raising human beings, educating young people and transferring culture to next generations was largely carried out through such narratives. Therefore, each narration is a compasition of an "implicit program" with the function of giving messages and enculturation. Considering these separately and revealing these values in the ancient times are of great importance to reach the values carrying the society to the present. (Cemiloğlu, 2006, p. 266). Therefore, all such narrations can be used as a resource in the value education.

Considering the use of myths in the value education Karakuş \& Iş1k (2017) carried out a study entitled the use of myth, epic and fairy tales in early childhood period. They argued that using these in education may encourage children to acquire some national values, including respect for parents, having religious and national values, courage, bravery and justice. Beşik, (2011) also analysed the topic in his MA thesis entitled A Study on the Myths in the Works of Cengiz Aytmatov in terms of our Traditional Education. It was found that in the myths covered in the works of Cengiz Aytmatov there are numerous references to national and religious values as well as universal values which suggests that legends can be employed for educational purposes.

There are many definitions about legends. In Turkish the word is "efsane" which was borrowed from Persian. In the European languages "legend, legenda, leggenda, leyenda" are used to denote it all of which have a common origin from Latin "legendus". There are also some variations such as German "sage, saga", Greek "mythe/myhtos", Arabic "ustûre, esâtir" and Russian "predaniya, skaz" (Uyanıker, 2011, p. 46); Dégh (2005) argues that it is a narration that was about past events, and was formulated in a particular artistic order and designed to be told to a third party (cited in Zeki Güven 2014). Turkish Language Society (2018) regards it as a fictitious story that has been told from the ancient periods and is about extraordinary beings and events.

\section{The Use of Documentaries as an Educational Tool}

The most important goals of today's education systems include the following: to improve awareness of individuals about the changing world and current agenda; to make it possible for them to deal with and discuss the contemporary issues in a critical context and to ask questions and offer views about these issues; to ensure that individuals have a global understanding of human rights and current affairs that have direct and significant effects on human life and to ensure that individuals can assume responsibility in solving social problems. Today students often use films and television to access information. Although books and other informative texts are basic resources for learning, teachers should try to increase the visual stimuli in the teaching and learning process by taking into account the recent characteristics of the students. In short, new methods and approaches should be employed to improve the moral, personal and ethical development of young people and children (Kuchukhidze, 2016). There are 
many kinds of programs on television. One of these television programs is documentaries which are the most informative type. Therefore, documentaries can be easily used for educational purposes.

The aim of the study is to analyse the use of a documentary entitled Talisman of the City which was broadcasted on TRT TV website in teaching the values included in the educational prgram for the social studies course. The reason for choosing it is the documentary contains several myths and legends about different cities of Turkey (for instance, Walls of Istanbul, Maiden's Tower, Suleymaniye Mosque). The majority of the episodes are about different myths and legends while some episodes deal with the same topic based on different myths. The documentary suggests that there may be more than one motive for an event or a historical building. It also defines myths as verbally important cultural elements that reflect the culture of society and contain traditions, history and values in this culture. The reason for analysing this documentary is that it cntains many values that are included in the educational program of the course of social studies. Myths are recommended to be used as a resource in Social Studies course program. Therefore, it is thought the analysis of the documentary is valuable for the course. It is hoped that the research will contribute to the practitioners of the value education.

\section{Methodology}

\section{Research Design}

The study was designed as a qualitative research and the document analysis was employed. Document analysis is defined as the analysis of written materials containing information about the facts and events to be studied. Written or visual materials such as films, videos, pictures and photographs are also covered by the document analysis (Yıldırım \& Şimşek, 2016). All types of texts can be examined through the document analysis (Sönmez \& Alacapınar, 2014). The document analysis can provide a number of convenience to the researcher with access to pictures, videos and internet resources as a source of data which are previously difficult-to-reach areas (Güler, Taşkın \& Halıcioğlu, 2015). The term document is used as an umbrella term which refers to visual and physical materials. This word contains communication materials in the broadest sense, including newspapers, novels, anecdotes, memories and diaries (Merriam 1998, cited in Konak 2017, p. 56). In this research the document which is titled "The Talisman of the City" is analyzed as a document. There are many studies (Konak, 2017; Selanik-Ay\&Korkmaz， 2017; Tozduman-Yaralı\&Avc1， 2017; Bayır\&Günşen, 2017; Kalayc1, 2015; Özyürek\&Kaya\&Yeşil\&Karadaş, 2018; Ayberk; 2018; Morsünbül, 2015; Tofur, 2018; Durdu Zor, 2017; Özdemir Erem\&Y1lmaz, 2017) that analyze media products with document analysis. Therefore the document analysis is used for this research.

\section{Data Collection}

The data of the study were collected from a documentary entitled "Talisman of the City" using the document analysis. The documentary was broadcasted on TRT TV website and a total of 50 episodes was analysed. 
Analysis. The study analysed the use of a documentary entitled Talisman of the City which was broadcasted on TRT TV website in teaching of eighteen values included in the educational program for the social studies course (Justice, giving importance to family unity, independence, peace, scientific, diligence, solidarity, sensitivity, honesty, esthetics, equality, freedom, respect, love, responsibility, saving, patriotism and charity). Each episode was transcribed and the values given above were looked for in the texts. The data were examined using the content analysis. The content analysis is a second reading to identify implicit elements that affect the individuals (Bilgin, 2014, p. 1). Simon and Burstein (1985) defined the content analysis as the process of analyzing content in a systematic way by examining the written and oral materials and quantifying them by coding based on clear instructions (Tavşancıl \& Arslan 2001, p. 19). The content analysis is a research technique that investigates the content of communication depending on the predetermined categories. The content analysis can be used to examine the all kinds of textual, audio-visual content and documents, including newspaper articles or news, television news, films, television series and documentaries (Geray, 2006, p. 147). The findings identified in each episode are given in tables. Direct quotations from the related episodes are used to support the findings.

\section{Findings}

In this section the findings identified in each episode are given in tables and the direct quotations from the related episodes are used to support the findings. The episodes are represented using the following abbreviations "E.1, E.2... etc.". Figure 1 below shows the myths about justice found in the documentary entitled Talisman of the City:

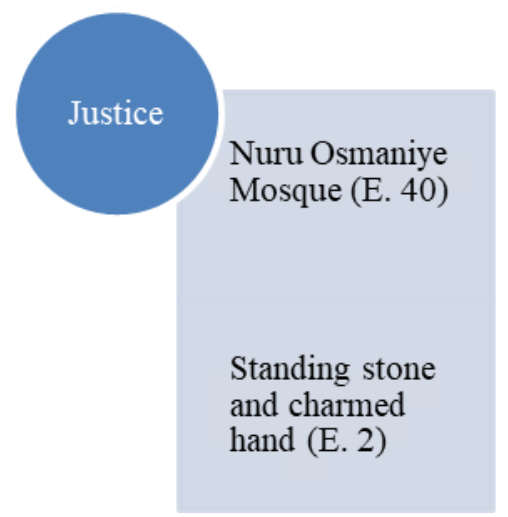

Figure 1. Episodes of the documentary entitled Talisman of the City which contain the value of justice

In two episodes of the documentary mentioned in Figure 1 the value of justice is narrated as follows:

The woman did not agree for the destruction of her hut to build a mansion, but the ruler rejected her wish and built it there. Then, the woman went to Kurtubaya and complained to Kadi Bashir. Kadi Bashir went to the garden of the ruler and wanted him to give him a bag full of sand. However, the ruler could not lift the bag. Kadi Bashir said: Look you cannot a simple bag, how would you lift the load of her land hereafter (Nuru Osmaniye Mosque, E. 40). 
The purpose of the Byzantine emperors to make this column was to ensure fairness in shopping. Therefore, traders called it fair. People who shopped came near the statue and put money in their palms. When the talismanic statue closed its palms they believed that the price given to anything was fair (Standing stone and charmed hand, E. 2).

The following figure shows the episodes of the documentary in which the value of paying importance to family unit is found.

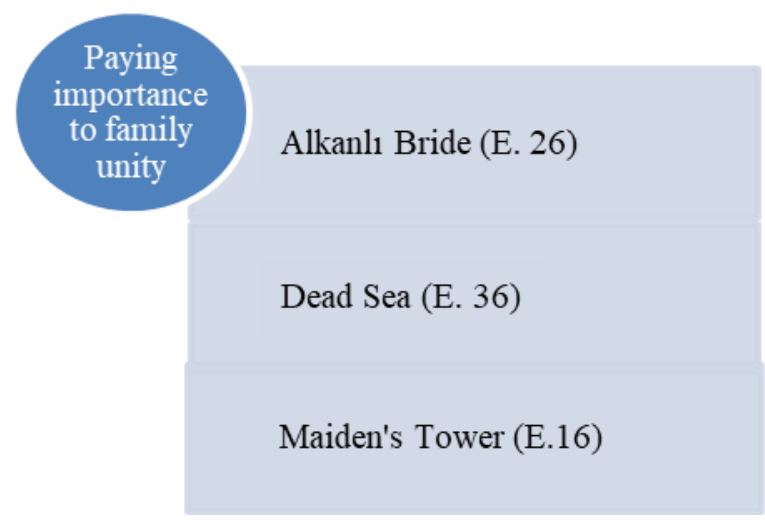

Figure 2. Episodes of the documentary entitled Talisman of the City which contain the value of paying importance to family unity

In three episodes of the documentary mentioned in Figure 2 the value of paying importance to family unity is narrated as follows: The mother-in-law and brothersin-law, who do not like their bride, let her and her child go to bride's village. They went with her for a while, but then they left her on the road (Alkanlı Bride, E. 26).

One day father and his son were on the ship and storm broke out. The son told his father about the sheltered bay around here. However, his father rejected his suggestion. Then they started a fight and while the ship would hit the full rock, the father threw his son into the sea (Dead Sea, E. 36).

Constantine had a daughter whom he loved and flickered upon... One day the emperor gathered all his fortune-telling and astrologers and asked about his daughter's future. They told the emperor that she would die as a result of snake bites when would be eighteen years old. In order to avoid it the emperor ordered the construction of a tower in the middle of the sea where snakes could not go. Following the completion of the tower his beautiful daughter began to live there (Maiden's Tower, E.16).

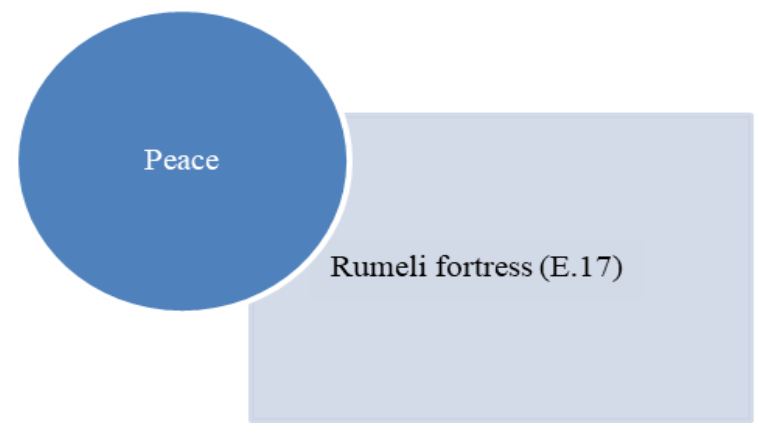

Figure 3. Episodes of the documentary entitled Talisman of the City which contain the value of peace 
In one episode of the documentary mentioned in Figure 3 the value of peace is narrated as follows:

Fatih Sultan Mehmet wanted to build a fortress for himself across the Anadolu fortress. But that land belonged to The Byzantine Empire. The Ottoman State did not want to destroy its relations with the Empire and therefore, it decided to make a friendly request for the land (Rumeli Fortress, E. 17).

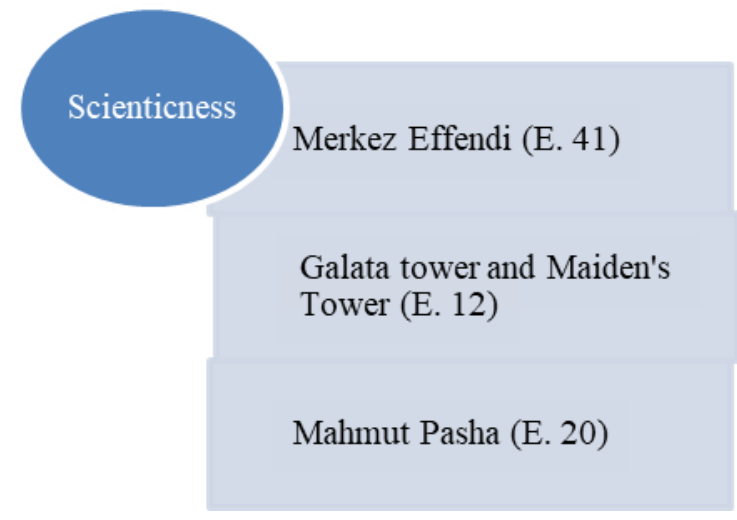

Figure 4. Episodes of the documentary entitled Talisman of the City which contain the value of scientificness

In three episodes of the documentary mentioned in Figure 4 the value of scientificness is narrated as follows:

Mahmut Pasha was cofounder of the madrasahs of Tetimme ve Sahn-1 seman together with Ali Tusi. In addition, he was the manager of the first libraries in İstanbul. He was friend of major sheiks and scientists of the period and was a supporter of many scientific works by providing material and moral support (Mahmut Pasha, E. 20).

During the first half of the 17. Century under the reign of 4. Murat Hazerfen Ahmet Çelebi trained in flight on the Ok (arrow) Square and put on his back his eagle wings. In 1638 he flew from the galata tower. It is one of the most interesting events about the tower (Galata tower and Maiden's Tower, E. 12).

Merkez Effendi was a master in medicine. When he lived in Manisa he made a putty from 41 spices. They used it to treat different diseases (Merkez Effendi, E. 41).

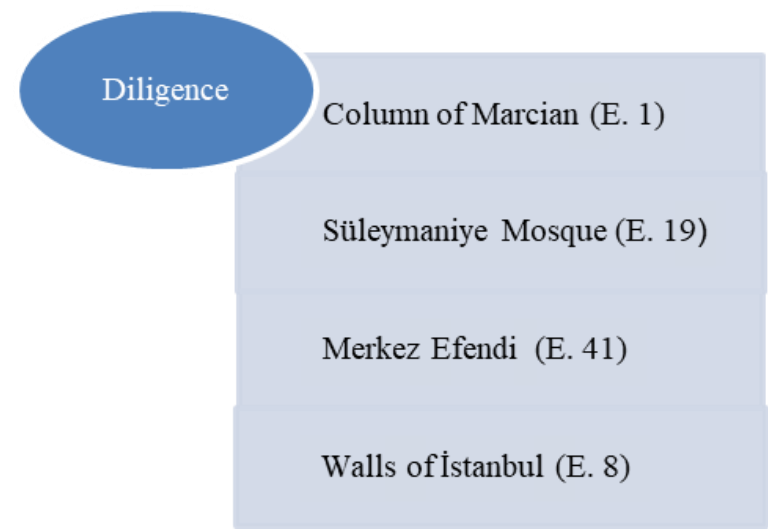

Figure 5. Episodes of the documentary entitled Talisman of the City which contain the value of diligence 
In four episodes of the documentar mentioned in Figure 5 the value of diligence is narrated as follows:

Despite all his efforts, this time he could not move the stone (Column of Marcian, E. 1).

After collecting all materials Sinan built the Süleymaniye mosque as a huge building in just two months (Süleymaniye Mosque, E. 19).

After a while in this madrasa built for his own name Merkez Effendi trained students. At the same time he worked a dervish lodge built on the orders of Kanuni Sultan Süleyman outside the walls of the Topkap1 Place and again trained students (Merkez Effendi, E. 41).

High and non-exceedable city walls were built during the Byzantine period to protect Istanbul from enemy invasions during the 7. Century (Walls of Istanbul, E.8).

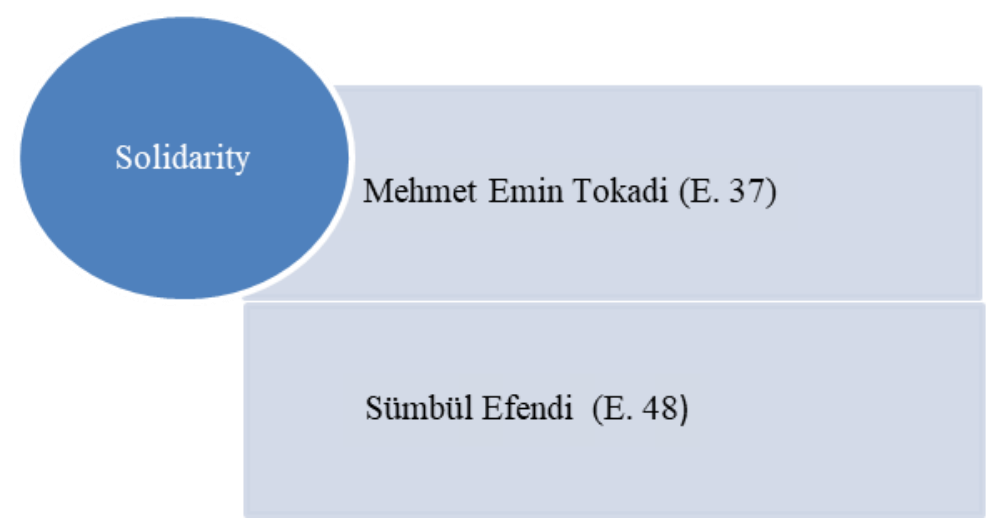

Figure 6. Episodes of the documentary entitled Talisman of the City which contain the value of solidarity

In four episodes of the documentary mentioned in Figure 6 the value of solidarity is narrated as follows:

Allah accepted our prayers. Mahmut Khan reached the victory. He was praised by the Sultan. We prayed for him and he reached the victory (Mehmet Emin Tokadi, E. 37).

Sümbül Efendi knew the future of the Sultan. He was waiting in the garden of the mosque with all poors and dervishes. The Sultan was almost enthralled and understood looking at the eyes of Sümbül that the sin of washing the mosque was too big to measure (Sümbül Efendi, E. 48).

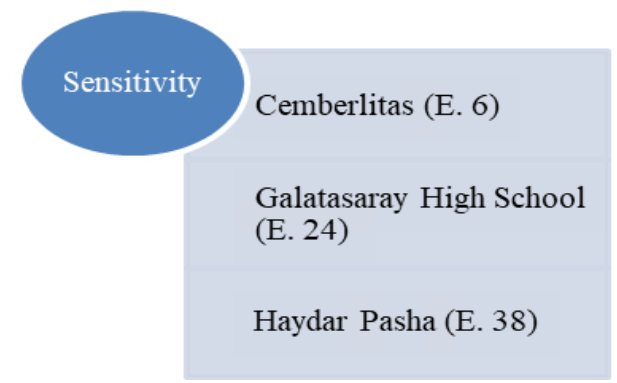

Figure 7. Episodes of the documentary entitled Talisman of the City which contain the value of sensitivity 
Selanik Ay, T., Öncü, Z. (2019) / An analysis of the documentary entitled talisman of the city....

In three episodes of the documentary mentioned in Figure 7 the value of sensitivity is narrated as follows

The Sultan thought that after him the coming rulers would not know the worth of these blessed works which would be a great sin. Therefore, he kept the gifts in his treasure (Cemberlitas, E. 6).

Cemberlitas is maybe the sign of the fact that protecting our values is very important and such values are ultimately significant for our country that we could not forget (Cemberlitas, E. 6).

Gül Baba said: "Long live my Sultan. Although living here is better for me, but you may build a school here to train our children. Then the Sultan promised him to build a school here (Galatasaray High school, E. 4).

Haydar Baba tomb was renovated and illuminated. Then the tomb became a place where passengers stopped and prayed before they departed by train (Haydar Pasha, E. 38).

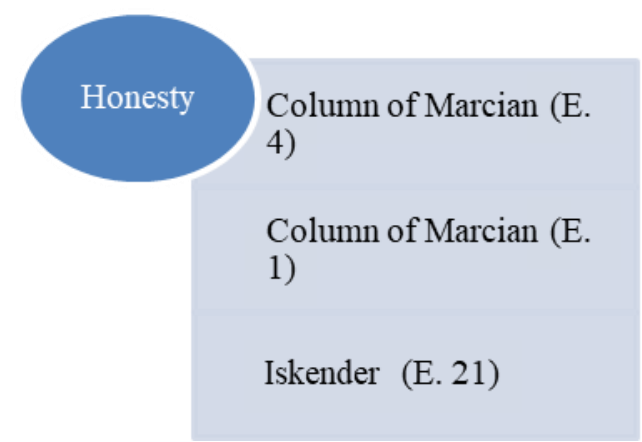

Figure 8. Episodes of the documentary entitled Talisman of the City which contain the value of honesty

In three episodes of the documentary mentioned in Figure 8 the value of honesty is narrated as follows

Justin, one of the Byzantine emperors, ordered his sister-in-law to be tested passing under the Column of Marcian. She stood across the emperor and said that she was clean and sinless up a white marble and rejected the order of Justin. She gave her own death judgment by refusing to be tested (Column of Marcian, E. 4).

The girl suspected after a while. She said silently herself that the gin told me Hagia Sophia was over and that I should go there to see it herself. When she arrived Hagia Sophia she saw that the construction was not completed. Then she understood that the gin deceived her (Column of Marcian, E.1).

Oh Iskender don't waste your time, you cannot fishing. Fishing does not like conquer the country. Every job has its own consciousness (Iskender, E. 21). 


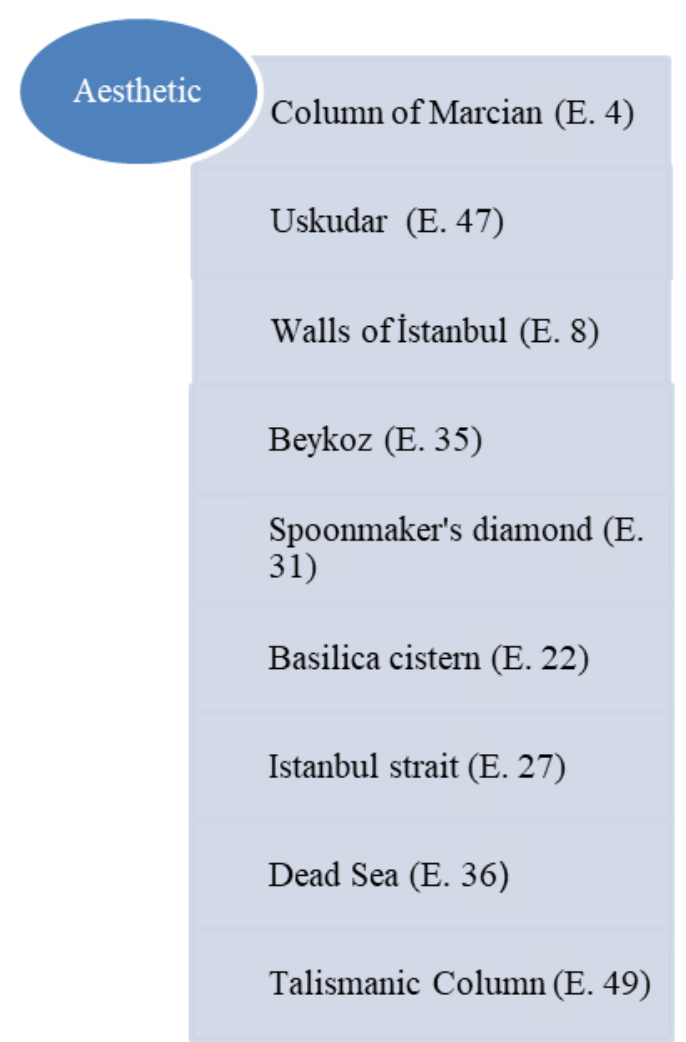

Figure 9. Episodes of the documentary entitled Talisman of the City which contain the value of aesthetic

In nine episodes of the documentary mentioned in Figure 9 the value of aesthetic is narrated as follows:

At the top of the column there was a statue which is a portrait of a beautiful fairy (Column of Marcian, E. 4).

Istanbul is called the queen of the cities. Its beauties have made this city as the most desirable city throughout history (Walls of İstanbul, E. 8).

It is also known as Basilica cistern which is one of the splendid buildings in Istanbul (Basilica cistern, E. 22).

Istanbul is one of Turkey's largest and most beautiful cities (Istanbul Strait, E. 27).

The Spoonmaker's diamond is 86 carat and is a great work with a circumference containing 49 diamonds in Paris (Spoonmaker's diamond, E. 31).

Beykoz is one of the most long-established and beautiful neighborhoods of Istanbul which is surrounded by the districts of Cekmekoy, Uskudar and Umraniye"..... "Beykoz has been one of the most beautiful districts of Istanbul throughout the history (Beykoz, E. 35).

The Dead is in Fethiye district of Mugla and was selected as the most beautiful sandy beach in the world in 2006 (Dead Sea, E. 36).

In the west of Üsküdar there are the most magnificent views of the Bosporus and Üsküdar was a province until 1926 (Üsküdar, E. 47). 
At the top of the column there was a statue which is a portrait of a beautiful fairy (Talismanic Column, E. 49).

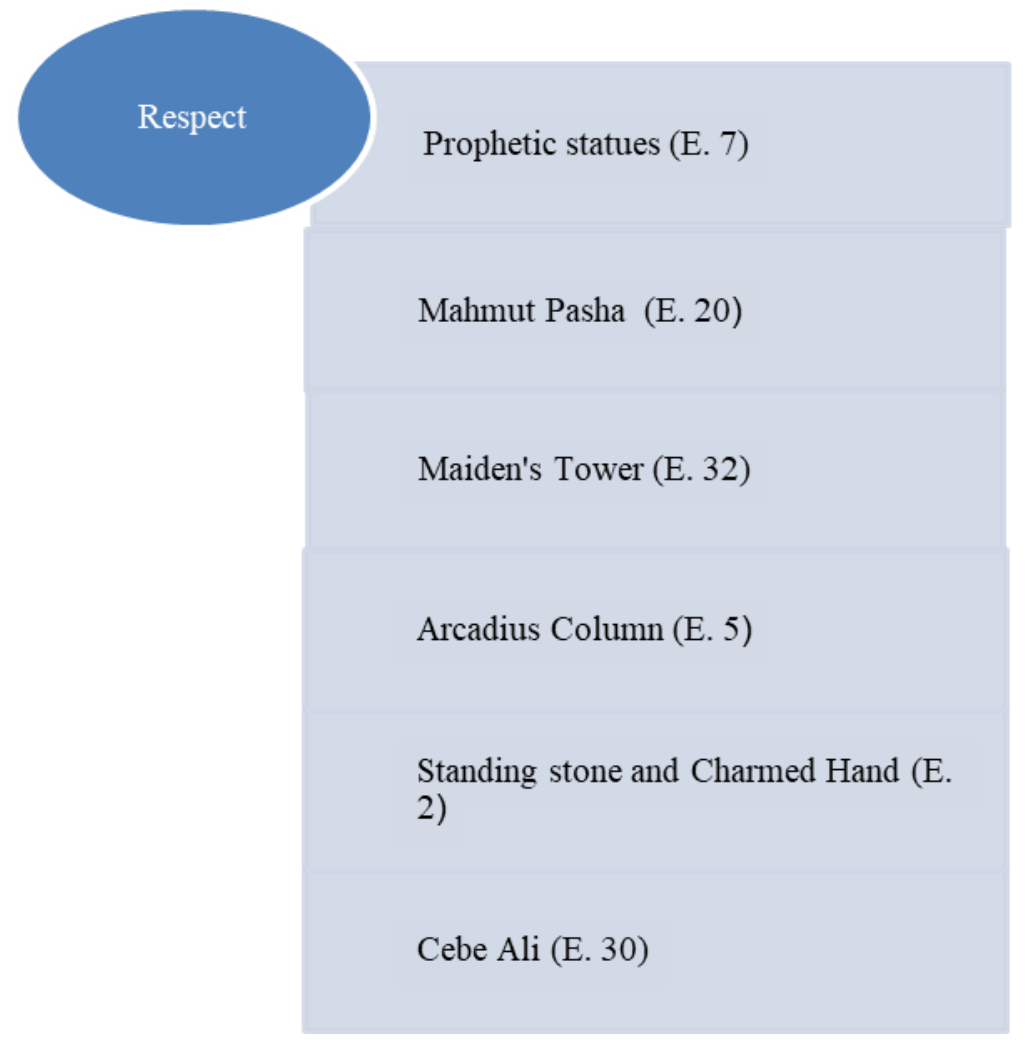

Figure 10. Episodes of the documentary entitled Talisman of the City which contain the value of respect

In six episodes of the documentary mentioned in Figure 10 the value of respect is narrated as follows:

When the people of Istanbul saw the stairwells of the crusaders on the Venetian ships, they realized the warning of these sculptures. Then they tried to smash these sculptures with stones and hammers to bring bad luck to the invaders (Prophetic statues, E. 7).

Mahmut Pasha was one of the leading statesmen of the Ottoman State. He was appreciated by Fatih Sultan Mehmet Khan for his intelligence, scientific knowledge and strong personality (Mahmut Pasha, E. 20).

After such a strong success, it is not suprising that a neighborhood is remembered with the most important person behind this success. Cebe Ali was a master warrior. There is a school named after him in the same neighborhood. Because it was thought that the true conquest is achieved by Education (Cebe Ali, E. 30).

Instead of screaming victory, their soldiers were watching him with tears on the ships. Because his wife, Damalis, dead in the war whom Carls loved so much and who was always with him in all wars (Maiden's Tower, E. 32).

Today we keep thinking that wish our buildings were talismanic and could stand still against all barriers (Arcadius Column, E. 5). 
The owner of the horse was so furious that he cut the hand of the talisman statue with his machete (Standing stone and charmed hand, E. 2).

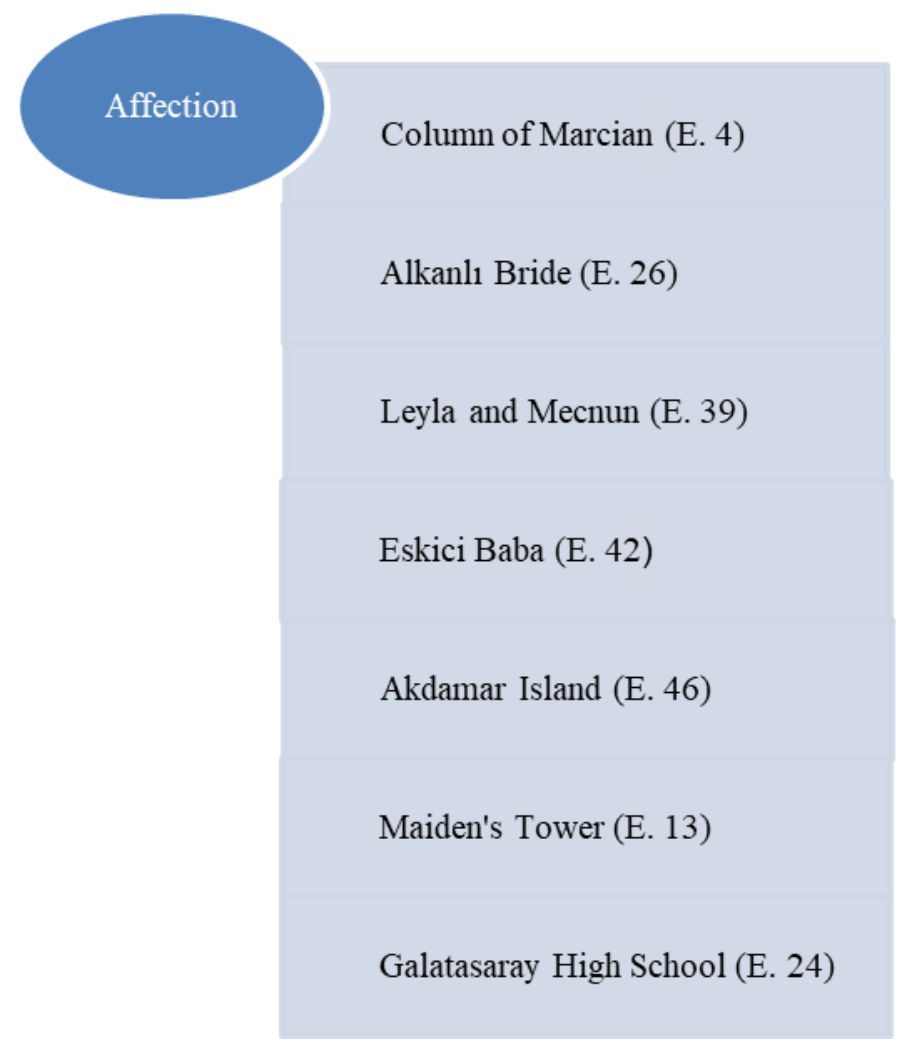

Figure 11. Episodes of the documentary entitled Talisman of the City which contain the value of affection

In seven episodes of the documentary mentioned in Figure 11 the value of affection is narrated as follows:

The girl chatting with her teacher at the garden of her palace following each course was the only one who knew that his wife was pregnant. So every day she took a flower from the graden and sent it to the teacher's wife (Column of Marcian, E. 4).

Suddenly, her husband gets sick and she do not leave him alone. It will not be enough although she tries every way to make her husband better (Alkanlı Bride, E. 26).

Leyla cannot live without Mecnun and after a short period she dies. Mecnun heard that Leyla died. He went to her grave and cried there (Leyla and Mecnun, E.39).

Greek people and Eskici Baba love one another so much. He did not want them to be harmed (Eskici Baba, E. 42).

The love of Tamara and Turkish man was so great that the imprisonment of Tamara by the monk in the island hindered their love. The young man went to the island every night (Akdamar Island, E. 46). 
Leandros could no longer stand the longing for Hero who returned to the tower. As a propeller who wanted to get to the light, he lost himself and jumped into the water and swimmed towards the torch to reach his lover (Maiden's Tower, E.13).

One of the people who involved in the conquest of Istanbul by II. Mehmet was a nature lover. He was an old man called Gül Baba planted roses and other flowers everywhere (Galatasaray High School, E. 24).

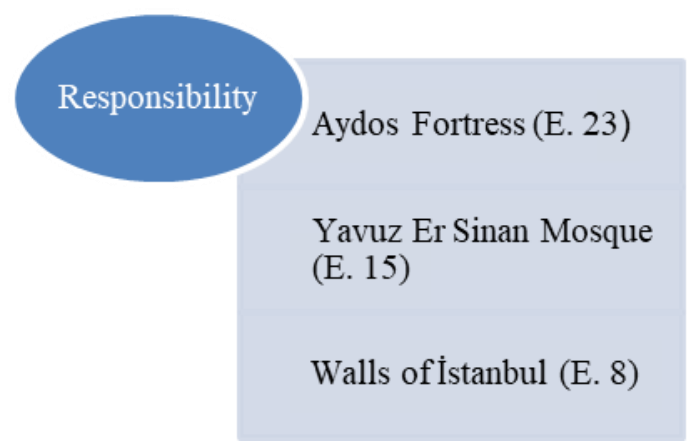

Figure 12. Episodes of the documentary entitled Talisman of the City which contain the value of responsibility

In three episodes of the documentary mentioned in Figure 12 the value of responsibility is narrated as follows:

Ottomans pretend to escape from the castle and then the soldiers in the castle relaxed the tight protection (Aydos fortress, E. 23).

He ordered the Janissary to open the door. One of the soldiers stated that he did not open the door and let them enter the room although Fatih became angry and shouted at him (Yavuz Er Sinan Mosque, E. 15).

Every structure that represents the birth of civilization must have a protector on the shoulder. However, these protectors should not be limited only to spiritual beings. In other words, it should not be forgotten that there is a lot of work to do by people on this subject (Walls of İstanbul, E. 8).

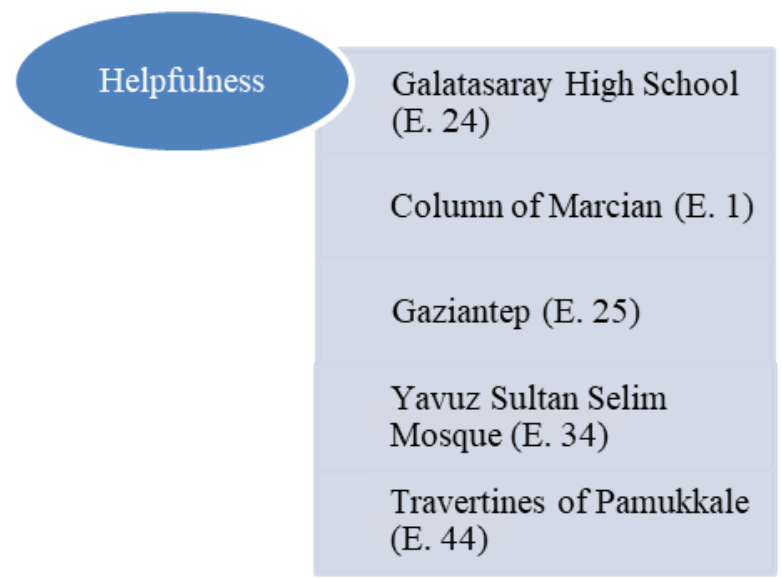

Figure 13. Episodes of the documentary entitled Talisman of the City which contain the value of helpfulness 
In five episodes of the documentary mentioned in Figure 13 the value of helpfulness is narrated as follows:

He went to the Maiden's Tower without harming Üsküdar with a boat. He saved the king's daughter and his treasures (Battal Gazi, E. 10).

Happily with the wish of this good man who wanted to have a school for children without asking for anything for himself, many children have been educated in the same school for centuries (Galatasaray High School, E. 24).

He said that I heard that a church was being built in Hagia Sophia and that in order to help it I am bringing this stone to the construction site (Column of Marcian, E.1).

Elderly poor dervish saw two girls working at the head of the garden. He approached the eldest and asked for some food to feed himself. The girl gave him an onion. He took it and said to her "hope you reap what you sow". Then he approached the youngest girl and again asked for food. The little girl welcomed him and said "I cooked helva this morning. Sit here and eat it (Gaziantep, E. 25).

An old woman came nearby the masters and wanted to give her money to the masters to use in the construction of the mosque (Yavuz Sultan Selim Mosque, E. $34)$.

The man who saw the blood in the water broke into the water and fearlessly removed her from there. After saving the young girl, he took her to his home with his horse and tried his best to make her healed (Travertines of Pamukkale, E. 44).

It is also found that there are some episodes of the documentary entitled Talisman of the City which contains no reference to the values given in the educational program of the social studies course. These episodes are given in Table 1 as follows:

Table 1

Episodes of the documentary entitled Talisman of the City which contain no reference to the values given in the educational program of the social studies course

\begin{tabular}{ll}
\hline Episode & Myth \\
\hline 3 & Maiden's Tower \\
9 & Walls of Istanbul \\
11 & Jeweled Minaret \\
14 & Walls of İstanbul \\
18 & Süleymaniye Mosque \\
28 & Ferhat and Şirin \\
29 & Church of St. Mary of the Spring \\
33 & Kanlica \\
43 & Kirkpınar wrestling \\
45 & Conquest of Istanbul \\
50 & Yahya Effendi \\
\hline
\end{tabular}

Table 1 indicates that the documentary has some episodes that are not related to the values included in the educational program of the course of social studies: Maiden's Tower, Walls of Istanbul, Jeweled Minaret, Walls of Istanbul, Süleymaniye Mosque, Church of St. Mary of the Spring, Ferhat and Şirin, Kanlica, Kirkpınar wrestling, the Conquest of Istanbul and Yahya Effendi. 
In the analysis of the documentary it is found that some episodes also contained cultural heritage elements in addition to the values. It can be argued that cultural heritage elements are closely related to the values. More specifically, in the teaching of some values such as patriotism and independence the elements of cultural heritage can be employed. Therefore, it was decided that the episodes should be analysed in order to these cultural heritage elements. It was found that these elements existed in the content or visual elements of the episodes which were found to have any reference to the values analysed. Some of these elements are about historical personalities or about historical places. Table 2 indicates the cultural heritage elements contained in the documentary entitled Talisman of the City.

Table 2

Episodes and the cultural heritage elements found

\begin{tabular}{|c|c|c|}
\hline Episode & Myth & Cultural Heritage Element \\
\hline 3 & Maiden's Tower & Maiden's Tower \\
\hline 5 & Arcadius Column & $\begin{array}{l}\text { Cerrah Pasha Neighborhood, Evliya Çelebi, Arcadius } \\
\text { Column }\end{array}$ \\
\hline 6 & Cemberlitas & Helena, Jesus, Constantine, Walls of İstanbul, Jerusalem \\
\hline 8 & Walls of İstanbul & Constantine, Istanbul, Rome \\
\hline 9 & Walls of İstanbul & Topkap1 Palace, Yedikule, Constantine \\
\hline 10 & Battal Gazi & Evliya Çelebi, Battal Gazi Maiden’s Tower \\
\hline 11 & Jeweled Minaret & $\begin{array}{l}\text { Kanuni, Sheikh Tahmasb, Architect Sinan, Süleymaniye } \\
\text { Mosque }\end{array}$ \\
\hline 12 & $\begin{array}{l}\text { GalataTower and } \\
\text { Maiden's Tower }\end{array}$ & $\begin{array}{l}\text { 4. Murad, Hazarfen Ahmet Çelebi Galata Tower, Maiden's } \\
\text { Tower, Ok Square }\end{array}$ \\
\hline 13 & Maiden's Tower & Afrodit, Aş1k Veysel, Maiden’s Tower \\
\hline 14 & Walls of Istanbul & Fatih, Atilla, Konstantin, Theodosius, Walls of Istanbul \\
\hline 15 & $\begin{array}{l}\text { Yavuz Sinan } \\
\text { Mosque }\end{array}$ & Fatih, Yavuz Er Sinan Mosque \\
\hline 16 & Maiden's Tower & Constantine, Hagia Sophia, Maiden’s Tower \\
\hline 17 & Rumeli Fortress & $\begin{array}{l}\text { II. Mehmet, Yıldırım Beyazıd, Constantine, Anadolu } \\
\text { Fortress, Rumeli Fortress }\end{array}$ \\
\hline 18 & $\begin{array}{l}\text { Süleymaniye } \\
\text { Mosque }\end{array}$ & Kanuni, Architect Sinan, Süleymaniye Mosque \\
\hline 19 & $\begin{array}{l}\text { Süleymaniye } \\
\text { Mosque }\end{array}$ & Kanuni, Architect Sinan, Süleymaniye Mosque \\
\hline 20 & Mahmut Pasha & $\begin{array}{l}\text { Fatih, Ali Tusi, Mahmut Pasha Covered Bazaar, Mahmut } \\
\text { Pasha Turkish Bath, Mahmut Pasha Caravanserai }\end{array}$ \\
\hline 22 & Basilica Cistern & Covered Bazaar, Kınalı Island, Basilica Cistern \\
\hline 23 & Aydos Fortress & Orhan Gazi, Konur Alp, Abdurrahman Gazi, Aydos Fortress \\
\hline 25 & Gaziantep & Hot Pepper, Pistachio \\
\hline 27 & Istanbul Strait & Iskender, İstanbul Strait \\
\hline
\end{tabular}




\begin{tabular}{lll}
\hline 28 & Ferhat and Şirin & Ferhat and Şirin \\
\hline 31 & $\begin{array}{l}\text { Spoonmaker's } \\
\text { diamond }\end{array}$ & $\begin{array}{l}\text { 4. Mehmed, Köprülü Fazıl Ahmet Pasha, Topkapı Palace, } \\
\text { Spoonmaker's diamond }\end{array}$ \\
\hline 32 & Maiden's Tower & Filip King of Macedonia \\
\hline 34 & Kanlıca & Mihrabat Grove, Kanlıca \\
\hline 36 & $\begin{array}{l}\text { Yavuz Sultan } \\
\text { Selim } \\
\text { Mosque }\end{array}$ & Yavuz Sultan Selim, Yavuz Sultan Selim Mosque \\
\hline 38 & The Dead Sea & The Dead Sea \\
\hline 39 & Haydar Pasha & III. Selim, Haydar Pasha \\
\hline 40 & Leyla and Mecnun & Leyla, Mecnun \\
\hline 43 & $\begin{array}{l}\text { Nuru Osmaniye } \\
\text { Mosque }\end{array}$ & III. Osman, I. Mahmut, Nuru Osmaniye Mosque \\
\hline 44 & $\begin{array}{l}\text { Kirkpınar } \\
\text { Wrestling }\end{array}$ & Orhan Gazi, Süleyman Pasha, Kirkpınar Wrestling \\
\hline
\end{tabular}

As can be seen in Table 2 in all episodes which have no reference to the values there are indications of the elements of cultural heritage. In some episodes the indications to these elements are found either in the content or in the visual materials. However, in the myths about the Church of St. Mary of the Spring, the Conquest of Istanbul and Yahya Effendi such indications are found to exist only in visual materials. The elements of cultural heritage about historical places which are found in the documentary are given as follows: Maiden's Tower, Cerrah Pasha Neighborhood, the walls of Istanbul, Jerusalem, Topkap1 Palace, Süleymaniye Mosque, Yedikule, Pamukkale Travertenleri, Nuru Osmaniye Mosque, Yavuz Sultan Selim Mosque, Mihrabat Grove, Kanlica, Istanbul Strait, Arcadius Column, Ok Square, Yavuz Er Sinan Mosque, Hagia Sophia, Anadolu Fortress, Rumeli Fortress, Mahmut Pasha Bedesten, Mahmut Pasha Turkish Bath, Mahmut Pasha Caravanserai, Covered Bazaar, Kinalı Island, Church of St. Mary of the Spring, Aydos Fortress, Spoonmaker's diamond and the Dead Sea. The elements of cultural heritage about historical personalities which are found in the documentary are given as follows: Helena, Jesus, Hz. Muhammed, Constantine, Evliya Çelebi, Battal Gazi, Kanuni, Sheikh Tahmasb, Architect Sinan, 4. Murad, Hazarfen Ahmet Çelebi, Aphrodite, Aşık Veysel, Fatih, Atilla, Theodosius, Yıldırım Beyazıd, Ali Tusi, İskender, 4. Mehmed, Köprülü Fazıl Ahmet Pasha, Ferhat and şirin, Phillip the King of Macedonia, Yavuz Sultan Selim, Orhan Gazi, Konur Alp, Abdurrahman Gazi, III. Selim, Haydar Pasha, Leyla, Mecnun, III. Osman, I. Mahmut and Süleyman Pasha. In the documentary the ancient sports is represented by the Kirkpinar wrestling.

\section{Conclusion, Discussion and Suggestions}

The current activities in the value education in Turkey mostly include the distributing the texts in which the values are explained to the students and their families and the organization of the poetry, composition and painting competitions 
about the values to be taught (Şimşek, 2015, p.18). However, adopting different approaches and employing some interesting educational tools will make students much more interested in the course. In addition, these will make it possible to have efficient and productive value education. In the value education different media products, including documentaries, cartoons, animations, ads and short movies can be employed. It is also possible to use several literary types (poems, myths, tales, tongue twisters, anecdotes and folk stories, etc.) in the value education. In the study the use of a documentary entitled Talisman of the City was analysed in terms of the teaching the values included in the educational prgram for the social studies course. The findings indicate that the documentary entitled Talisman of the City does not contain all 18 values included in the educational program of the course of social studies. The frequently mentioned values in the documentary are found to be aesthetics, affection, respect and helpfulness. The value of peace is found to be less mentioned in the documentary. The missing values are found to be savings, patriotism, independence, freedom and equality. As the direct quotations from the episodes of the documentary shows the values are given through both positive and negative statements of which the former is much more frequent. In addition, these statements about the values are implicitly and explicitly given through the events, the behavior of people, attitudes towards the events, words and expressions of the narrator.

Studies on different types of media products in the context of values education have been found in the literature. The findings of the study are given as follows with a reference to the previous findings. The literary genres analysed in such studies are found to be magazines, newspapers and books. Deveci, Belet and Türe (2013) in their study entitled "Values found in the Dede Korkut Stories" found that these stories include the following values: the unity of family, affection, honesty, respect, aesthetic and courage in addition to honor, solidarity, patriotism, generosity, compassion, social and religious values. Şimşek (2015) analysed the values used in the novels by Kemalettin Tuğcu and concluded that these novels mostly contain the following values: affection, compassion, frugality, cooperation, winning through work, patience, religion and hospitality. Ercan (2014) examined a newspaper entitled Etfal in terms of the value education and found that the following values are given in the paper: diligence, friendship, respect for parents, unity, being decent, education, importance of education, giving importance to being healthy, being respectful, helpfulness, being frugal, avoiding arrogance and using time correctly. Akpinar (2015) in his study entitled "Value education activities based on the stories in Yağmur magazine" found that the major values contained in the stories are fairness, paying importance to religious beliefs, respect and affection. Konak (2017) studied the values in newspapers in a study entitled "An analysis of newspapers in terms of the value education" and found that the most frequeunt values are responsibility, paying importance to being healthy and to the unity of family and solidarity. Çapaoğlu and Okur (2015) analysed the values in the poems covered in the textbooks of the Turkish Language course and found that the most frequently stated values are love of human, love of nature and respect to the Turkish elders. Zeki 
Güven (2014) reported that in myths the values of love, respect, helpfulness, honesty and solidarity are mostly covered. Some of these findings are consistent with the current findings. The findings indicate that documentary entitled Talisman of the City does not contain all 18 values included in the educational program of the course of social studies. The frequently mentioned values in the documentary are found to be aesthetics, affection, respect and helpfulness. The value of peace is found to be less mentioned in the documentary. The missing values are found to be savings, patriotism, independence, freedom and equality.

It is generally reported that the use of the media products on the value education is mostly efficient. Different media work types have been analysed in relation to the value education. Arslan (2004) argued that such work has a significant effect on the knowledge, opinion, attitude, feelings and behaviors of individuals and that it may affect not only individuals but also social groups, organizations, social institutions as well as society and culture. Bayraktar (2014) argued that it is known that it is not possible to ensure the continuity and diversity of cultures by forcing modern man to produce old culture. Therefore, the transfer of oral culture products to digital culture environment is effective in the re-application of culture in different places and in the transfer of it to future generations. It is possible to argue that the use of television can be beneficial for the value education. Societies aim to transfer these values to the next generations. These values have important roles to play in the continuation of socities. The transmission of these values is one of the responsibilities of first families and then, of schools. The process of transferring values to individuals in schools is done especially through literary texts. More specifically, the following literary genres have this function: tales, ancdotes, folk tales, myths and legends (Zeki Güven, 2014).

Uçan (2018) suggests that cartoons address the viewer's visual and auditory perception and transform education into a fun process. Therefore, cartoons have a significant effect on viewers. Cartoons are mostly based on culture-based elements. Its production mostly involves verbal and written sources, epics, fairy tales, etc. Güler (2013) argued that the cultural functions of cartoons mostly involve teaching, demonstrating the truth, entertaining, educating through fun and social sharing.

There are some studies dealing with the effects of the use of cartoons for the value education. Aral and Kadan (2017) analysed eight cartoons in terms of universal values. They found the the most frequent values included in the cartoons are helpfulness, friendship, respect, love, tolerance and freedom. Selanik Ay and Korkmaz (2017) dealt with the analysis of cartoon entitled "Küçük Hezarfen" in relation to the values and cultural elements included in the social studies program. They found that the cartoon mostly make references to scientificness, helpfulness, affection and sensitivity. In the current study the values of aesthetics, affection, respect and helpfulness are mostly given. Sevim (2013) in her study entitled "Comparison of Cartoons in relation to the Value Education" focused on national and international cartoons. The common values in these cartoons are found to be fairness, care of family unity, diligence, honesty, respect, affection, responsibility and helpfulness. Aktan and Kılıç (2015) analysed the values given in the work 100 
basic studies and the values given in the educational program for the course of social studies. They found that in both sources the common values are affection, benevolence, respect, aesthetics and freedom. Karakuş (2016) Maysa and Bulut argues that in each episode of the cartoons a different tradition, custom and norm was given which revitalize the past values. They argues that cartoons are significant in the transfer of culture and the protection of intangible cultural heritage. Korukcu, Güngör, Ardahanlı (yılsı) examined the animated movies in terms of the value education and found that these movies cover numerous values, including protecting the environment, becoming a researcher, becoming a scientist, cooperation, aesthetics, diligence, entrepreneurship, tolerance, family safety, respect, sacrifice, acceptance of life, being polite, empathy, compassion, courage, loyalty and helpfulness. Aladağ and Karaman (2018) dealt with the significance of the use of short movies for the value education. The movies chosen were all award-winning movies from the EBA and were all appropriate for the developmental characteristics of the students. They concluded that such short movies can be used as significant tools for the teaching of values. It is seen that these findings obtained in the studies dealing with the use of cartoons and short movies in relation to the value education are compatible with the findings obtained in this study.

The findings of the studies on the use of media products for educational purposes are given as follows: Bektaş-Öztaşkın (2013) aimed to determine the effect of the use of documentaries on academical achievement and conscious awareness levels and found that the academical achievement of the experiment group in which documentaries are employed was significantly higher than that of the control group. Uçar and Karakuş (2017) in their study entitled "the use of documentary in the teaching of environmental issues in Social Studies courses" found that the documentaries designed with the 7E method which are also related to the topics to be taught have positive effects on student achievement and improve student attitudes towards environmental issues. Chiu Liu (2018) analysed the use of a documentary in the environmental education course for undergraduate students. It is found that the use of documentaries for undergraduate envirnment courses improved the students' focus on environmental issues, critical thinking, gaining multiple perspectives, professional environmental trends and interests. In the current study the documentary entitled Talisman of the City was employed in the course of social studies and found that the documentary contained the values included in the related educational program. Based on the findings the course outlines can be developed and the use of this documentary can be further analysed in experimental studies.

Given that historical narratives, legends, such as literary genres, individuals or groups have specific purposes and a fictionalized course their use may proivde some advantages. Readers remember details in literary product, try to make a connection between known and unknown, interpret it, try to understand the details of time and place about people and events related to the past from the narrators' perspective and also, employ their own interpretation ability. Thus the use of such literary genres makes it easy to understand the present and the past. It may make it possible to develop empathy and to understand history, different cultures and geographies. 
Therefore, it can be used as a powerful tool in learning different places and environments. In the study it is found in the episodes of the documentary that has no reference to values there are some cultural heritage elements. Therefore, such episodes have references to numerous historical places and persons. In this context it can be argued that the documentary can be employed as a device to establish the relationship between the past, the event, the person, the space and to keep the details in mind easily. Kaymakçı (2013) examined the use of verbal and literary genres in the textbooks of the social studies courses. It is found that myths are the least used genre in the textbooks analysed. However, myths should be used for the teaching of an effective social sciences courses due to the fact that they contain information about historical elements, historpical places and events and also, the values and cultural heritage elements. In short, myths should be employed much more frequeuntly in the courses and in the textbooks. The use of myths which integrate legends and technology such as the documentary analysed in the study in the course of social studies may improve student interest and student participation. Based on the findings of the study the following suggestions are offered:

- Experimental studies on the use of documentary in values education can be done in the context of social studies courses.

- Myths and documentaries can be used more in the value education.

- Verbal and written products are integrated with technology and used in different formats in the value education.

- Both pre-service and in-service activities can be designed to make pre-service teachers and teachers enable to transform literary work into digital formats.

\section{References}

Akbaş, O. (2004). Evaluation of the degree of reaching of affective goals at the elementery level in Turkish national education system (doctoral dissertation). Gazi University, Institute of Educational Sciences, Ankara.

Akbaş, O. (2008). Değerler Eğitimine bir bakış. Değerler Eğitimi Dergisi, 6(10), 9-27.

Akkaya, N. (2014). Keloğlan masallarında yer alan değerlerin incelenmesi. Akademik Sosyal Araştırmalar Dergisi, 2(1), 312-324.

Akpınar, A. (2015). Yağmur dergisindeki hikâyelerde değerler eğitimi: 2004-2014. (Master’s thesis). Çanakkale Onsekiz Mart University, Institute of Social Sciences, Çanakkale.

Aktan, O., Kılıç, A. (2015). Sosyal bilgiler öğretim programındaki değerleri 100 temel eserde bulunan değerlerin destekleme durumu. Değerler Ĕ̆itimi Dergisi, 12(30), 7-68.

Aladağ, E., \& Karaman, B. (2018). Değer eğitiminde kısa filmlerden yararlanma: örnek bir uygulama. Adnan Menderes Üniversitesi, Sosyal Bilimler Enstitüsü Dergisi, 5(1), 360377.

Arslan, A. (2004). Bir Sosyolojik Olgu Olarak Televizyon. Uluslararası Insan Bilimleri Dergisi, 1(1), 1-17.

Ayberk, C. (2018). Yer Bağlılı̆̆ Açısından Ters Yüz (Inside Out) Filminin Nitel Analizi. Coğrafi Bilimler Dergisi, 16(2), 273- 287. 
Selanik Ay, T., Öncü, Z. (2019) / An analysis of the documentary entitled talisman of the city....

Bayır, E. \& Günşen, G. (2017). Okul öncesi dönem çocuklarının en çok izledikleri çizgi filmlerin bilimsel açılardan analizi. Trakya Üniversitesi Eğitim Fakültesi Dergisi. 7(2), 746-761.

Bayraktar, Z. (2014). Geleneğin güncellenmesi bağlamında masaldan çizgi filme keloğlan tipi üzerine. İstanbul Üniversitesi Edebiyat Fakültesi Türk Dili Ve Edebiyatı Dergisi, 49(1), 19-51.

Bektaş- Öztaşkın Ö. (2013). Sosyal bilgiler derslerinde belgesel film kullanımının akademik başarıya ve bilinçli farkındalık düzeylerine etkisi. Eğitim Bilimleri Araştırma Dergisi, $3(2), 148-162$.

Beşik, Y. (2011). A study on stories (tales) in the works of Cengiz Aytmatov in terms of our traditional education (master's thesis). Ondokuzmay1s University, Institute of Educational Sciences, Samsun.

Bilgin, N. (2014). Sosyal Bilimlerde İçerik Analizi Teknikler ve Örnek Çalışmalar. Ankara: Siyasal Kitapevi.

Bozkurt, E. (2017). Values education with children's games (doctoral dissertation)). Gazi Üniversitesi. Institute of Educational Sciences, Ankara.

Çapaoğlu, E., Okur, A. (2015). Poetry in Turkish Textbooks Found in Middle School 8th Grade Values. Sakarya University Journal of Education, 5(3), 90-104.

Cemiloğlu, M. (2006). Eğitim bilimi açısından örtük program ve halk anlatılarının örtük program bağlamında değerlendirilmesi. Eğitim Fakültesi Dergisi, 19(2), 257-269.

Chiu Liu, S. (2018). Environmental education through documentaries: assessing learning outcomes of a general environmental studies course. EURASIA Journal of Mathematics, Science and Technology Education, 14(4), 1371-1381.

Çıkrıkçı, S. (1999). Çizgi filmlerin 5-6 yaş çocuklarının kavram gelişimi ve kazanımına etkisi (master's thesis). Ankara University, Graduate School of Social Sciences, Ankara.

Demiryürek, G. (2015). Values education in contemporary children's poetry (From 1980's up to today) (doctoral dissertation). Atatürk University, Institute of Educational Science, Erzurum.

Deveci, H., Belet, D., Türe, H. (2013). Values within dede korkut dede qorqut stories. Elektronik Sosyal Bilimler Dergisi, 12(46), 294-321.

Durdu Zor, S. (2017). Evaluation of costume features of the yoruk cartoon "maysa and bulut". Ulakbilge Dergisi, 5(18), 1987-2000.

Ercan, A.N. (2014). Analysis of Etfal Newspaper in aspect of text and values (master's thesis). Necmettin Erbakan Üniversitesi. Konya

Geray, H. (2006). Toplumsal Araştırmalarda Nicel ve Nitel Yöntemlere Giriş, Ankara: Siyasal Kitapevi.

Güler, A., Taşğın, S., \& Halıcıŏ̆lu, M.B. (2015). Sosyal Bilimlerde Nitel Araştırma, Ankara: Seçkin Yayıncılık

Güler, D., A., (2013). Soyutun Somutlaştırılması: Çizgi Filmlerin Kültürel İşlevleri. I. Türkiye Çocuk ve Medya Kongresi Bildiriler Kitabı: İstanbul, 207-216.

Hwang, H. S. (2017). Using stories for teaching primary social studies. Research and practice in humanities \& social studies education. 6(2), 64-78. 
Kalayc1, N. (2015). Analyses of the cartoon series from a gender equality perspective: pepee. Education and Science. 40(177), 243-270.

Karakuş, N. (2016). The evalution of the cartoon named maysa and bulut in terms of cultural elements. Mustafa Kemal Üniversitesi Sosyal Bilimler Enstitüsü Dergisi, 13(34), 134149.

Karakuş, N., Işı1k, N. (2017). The use of fairy tale, legend, and epic texts in early childhood period. Akademik Sosyal Araştırmalar Dergisi, 5(41), 118-133.

Kaymakç1, S. (2013). The usage situation of oral and written literary works in social studies textbooks. International Periodical for the Languages, Literature and History of Turkish or Turkic, 12(18), 293-310.

Konak, S. (2017). Günlük gazetelerin sosyal bilgiler öğretim programındaki değerler açısından incelenmesi (master's thesis). Afyon Kocatepe University, Graduate School of Social Sciences, Afyonkarahisar.

Korukcu, A., Güngör, M., \& Ardahanl1, Ö. (tarihsiz). "Animasyon filmlerin değerler bağlamında incelenmesi”. Retrieved from https://www.academia.edu/25987321/, 53-83.

Kuchukhidze, S. (2016). Using documentaries in social science instruction in schools as an effective source of value development for high school students". Journal of Education in Black Sea Region, 2(1), 116-129.

MEB. (2018). Sosyal Bilgiler Dersi (4-5, 6-7. sinıflar) Öğretim Programı, Retriewed from http://mufredat.meb.gov.tr/ProgramDetay.aspx?PID=354.

Modaqiq, S. H. (2017). Değerler eğitimi bağlamında İslam'da adalet kavramı (master's thesis) Ondokuz Mayıs University, Graduate School of Social Sciences, Samsun.

Morsünbül, Ü. (2015). Analyzing Honey (Bal), Milk (Süt) and Egg (Yumurta) Movies in Terms of Erikson's Theory of Psychosocial Development. Elementary Education Online, 14(1), 181-187.

Okudan, A. Y. (2010). Ĕ̈itim yöneticilerinin değerler eğitiminin önemi, etkileri ve uygulamalar hakkında görüşleri. (Master's thesis). Marmara Üniversitesi, İstanbul

Örnek, A. (2006). Türkiye'de Değişen Değerlerin Reklama Yansıması: Televizyon Reklamları Üzerine Bir İ̧̧erik Analizi (doctoral dissertation). Selçuk University, Graduate School of Social Sciences, Konya.

Özdemir Erem, H. N. \& Y1lmaz, O. (2017). An evaluation of "brotherhood" relationships in foreign cartoons. Ana Dili Eğitimi Dergisi, 5(4), 837-853.

Öztürk, C., Çoşkun-Keskin, S. \& Otluoğlu, R. (2014). Sosyal Bilgilerde Ebedi Ürün ve Yazılı Materyaller. Ankara: Pegem Yayıncılık.

Özyürek, A. \& Kaya, B. \& Yeşil, Z. \& Karadaş, İ. (2018). Keloğlan masalları çizgi filminin değerler açısından incelenmesi. Karabük Üniversitesi Sosyal Bilimler Enstitüsü Dergisi, $4,1-11$.

Selanik Ay, T. (2010). Social studies course student views on environmental awareness gaining media products to exploit. Uluslararası Avrasya Sosyal Bilimler Dergisi, 1(1), 76-93. 
Selanik Ay, T., Öncü, Z. (2019) / An analysis of the documentary entitled talisman of the city....

Selanik Ay, T. ve Korkmaz, Ç. (2017). An analysis of "küçük hezarfen" cartoon in terms of values and cultural elements stated in the educational program of social studies course. Batı Anadolu Ĕ̈itim Bilimleri Dergisi, 8(2), 49-62.

Sevim, Z. (2013). Comparison of cartoons in terms of values education (master's thesis). Uşak University, Graduate School of Social Sciences, Uşak

Şimşek, Ş. (2015). Values education in kemalettin tuğcu's novels. International Journal of Humanities and Education. 1(1), 79-104.

Sönmez, V., \& Alacapınar, F.G. (2014). Örneklendirilmiş Bilimsel Araştırma Yöntemleri, Ankara: Anı Yayıncilik.

Tavşanc1l, E. \& Aslan, A. E. (2001). Sözel ve Yazılı Materyaller için İçerik Analizi Ve Uygulama Örnekleri, Ankara: Epsilon Yayınları.

Tofur, S. (2018). School communication networks in cinematographic narration: case of the movie "the ron clark story. Eğitim Kuram ve Uygulama Araştırmalart Dergisi, 4(1), 54-67.

Tozduman Yaral1, K. \& Avc1, N. (2017). An investigation of a cartoon from the perspective of popular culture: rafadan tayfa. Gümüşhane Üniversitesi İletişim Fakültesi Elektronik Dergisi, 5(1), 449-470.

Turan, R. \& Ulusoy, K. (2014). Farklı Yönleriyle Değerler Eğitimi, Ankara: Pegem yayınları.

Türk Dil Kurumu, Güncel Türkçe sözlük. Retriewed from http://www.tdk.gov.tr

Uçan, B. (2018). Cultural codes of Turkish animation films. Uluslararası Sosyal Araştırmalar Dergisi, 11(55), 1135-1144.

Uçar, A. \& Karakuş, U. (2017). 6. Sınıf sosyal bilgiler dersi çevre konularının öğretiminde belgesel kullanımının ögrencilerin akademik başarı ve tutumlarına etkisi. Ahi Evran Üniversitesi Kırşehir Ĕ̈itim Fakültesi Dergisi, 18(3), 993-1009.

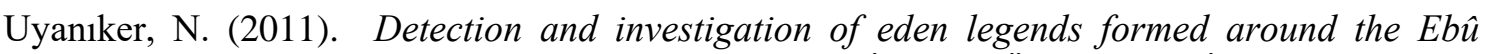
Eyyûb el-Ensârî̀?s tomb (doctoral dissertation). İstanbul Üniversitesi, İstanbul

Yıldırım, A. \& Şimşek, H. (2016). Sosyal Bilimlerde Nitel Araştırma Yöntemleri. Ankara: Seçkin Yayıncılık.

Yürük, S.E. (2015). The effect of digital story based values education on students' attitudes and value acquisiton (master's thesis). Firat University, Institute of Educational Sciences, Elazığ.

Zeki Güven, A. (2014). Investigation of Turkish legends in terms of values education. Mustafa Kemal Üniversitesi Sosyal Bilimler Enstitüsü Dergisi, 11(26), 225-246.

\section{Biographical Statements}

Tuğba SELANİK AY is Associte Professor at the Department of Social Studies Education/Afyon Kocatepe University/Turkey. Her studying area focuses on teaching social studies, teacher training and values education.

Zeynep ÖNCÜ is a master degree student at the Department of Social Studies Education/Afyon Kocatepe University/Turkey. 